\title{
CHARACTERISTICS AND USE OF MINERAL WATERS AND THERAPEUTIC MUDS FROM GRID VILLAGE AREA (BRAŞOV COUNTY)
}

\author{
Rodica MERET ${ }^{1}$, Liliana ZAHARIA ${ }^{2}$, Florina GRECU ${ }^{2}$
}

\begin{abstract}
Characteristics and use of mineral waters and therapeutic mud from Grid village area (Braşov County). This paper present some physicochemical characteristics of mineral waters and therapeutic mud in the Grid Village area, as well as aspects regarding their use. The study is based on the data collected from relevant bibliographic sources and field investigations and measurements carried out between 2012 - 2016. Chemically, the mineral waters from Grid Village area are chlorosodic (salinity $50 \mathrm{~g} / \mathrm{l}$ ), bicarbonated, and calcium-rich. The mineral salt deposit build-up on the soil stratum led to the formation of therapeutic mud, which has a compact granular structure with evenlydistributed chemical elements (except for sodium and chlorine) and high concentrations in oxygen and silicon. At present, the use of mineral waters and therapeutic mud from Grid village area is underdeveloped and strictly local.
\end{abstract}

Key words: mineral waters, physico-chemical characteristics, therapeutic mud, Grid Village.

\section{INTRODUCTION}

The healing properties of natural mineral waters and therapeutic mud are known since ancient times (Sukenik et al., 1999; Fraioli et al., 2011). Due to their benefits for human health, the use of these natural resources became very popular for medical purposes such as prevention, treatment, and rehabilitation $t$ of various diseases (Gutenbrunner et al., 2010; Bender et al., 2014). In Braşov region, the use of mineral waters began at the end of the $18^{\text {th }}$ century, in a time when the territory was still under Austro-Hungarian rule (part of the "Székely Land"), and the waters were considered to be Transylvania's "gold". This "richness" was being used in small spas - specially-designed bathing establishments - where tourists could enjoy the healing power of mineral waters. The Second World War put an end to spa activity, as the local infrastructure was completely or partially destroyed. After the nationalization process (initiated in 1948), efforts were put into restoring certain treatment centres (i.e. Băile Homorod, Băile Perşani, Băile Rodbav, and Băile Zizin). After the revolution in 1989, there have been continuous efforts to restore the most important spas (i.e. Băile Rodbav and Băile Perşani), while some were left (Băile Homorod, Băile Zizin).

1 Secondary School No 19, Aleea Lăcrămioarelor 2, Braşov, Romania, e-mail: kanord2908@yahoo.com (corresponding author)

2 University of Bucharest, Faculty of Geography, Bd. Nicolae Bălcescu 1, 010041, Bucharest, Romania, e-mail: zaharialili@hotmail.com; florinagrecu@yahoo.com 
This paper aims to highlight the physico-chemical specificities of mineral waters and mud in Grid Village area, as well as certain aspects regarding their use. Given the recent data, collected as a result of the authors' measurements of the Grid mineral and waters mud's physico - chemical parameters, and the information regarding their use, we believe the paper is relevant for supplementing and updating the existing scientific information on Grid's mineral waters and therapeutic mud.

\section{DATA AND METHODS}

The paper made use of three types of data: 1) information obtained from the analysis of scientific papers and cartographic documents; 2) data obtained from archival documents (monographies, photographs etc); 3) information obtained from field investigations carried out between 2012 and 2016. The last category included: observations on mineral water springs and on the current state of the old well called "Slatina"; measurements performed with a Hanna 9828 multiparameter for several physico-chemical parameters of mineral waters; water and therapeutic mud sampling, subsequently analysed at specialized laboratories (Water Management System Company, in Braşov; National Mineral Waters Society, in Bucharest; Institute for Multidisciplinary Scientific and Technological Research, in Târgovişte); interviews with locals. The main methods were: analysis, synthesis, observation, spring mapping, water and therapeutic mud sampling. The appropriate software programs were used for graphic and cartographic representations: Arc GIS 10.1, Global Mapper 12 and PhotoImpact, Excel.

\section{GENERAL GEOGRAPHICAL DATA ON THE GRID VILLAGE AREA}

Grid Village is located in the vicinity of Băile Perşani ( $\sim 5 \mathrm{~km}$ northeast) and approximately $50 \mathrm{~km}$ northwest of Braşov City. The small village, part of the Pârău township, can be reached via county road DJ $130 \mathrm{~B}$, which branches from national road DN 1 (E 68).

Geographically, it is located on the Perşani (Băile Perşani) - Grid - Veneţia de Jos line, and in the contact area of Făgăraş Depression and the western part of Perşani Mountains (Fig. 1); the alignment is also highlighted by the mineral water springs that emerge along the fault lines parallel to the mountains.

The Perşani - Grid - Veneţia de Jos area is located in a diapir formation section on the eastern side of the Transylvanian Depression, where Tortonian salt formations (Miocene) influence the properties of underground and surface waters. The geological formations in the Grid Village area are consistent with the general characteristics of the Perşani - Grid sector, and the springs emerge in the greenishor whitish-coloured dacitic tuff zone ("Perşani tuff"). The mineral waters originate from infiltrated precipitation water that washes over salt grains embedded in the earth's crust (Ciupagea et al,1970). The village is crossed from east to west by a 
creek called Grid, a right-side tributary of Perşani Creek; in the vicinity of the chlorosodic mineral spring, captured in a well called "slatină" in Romanian, there is another creek that flows in the same direction (east-west) - it is called Stearaşu, and it is characterized by sharp meanders, which is why this sector was named “Unghiuri” Valley (Modorcea, 2002).

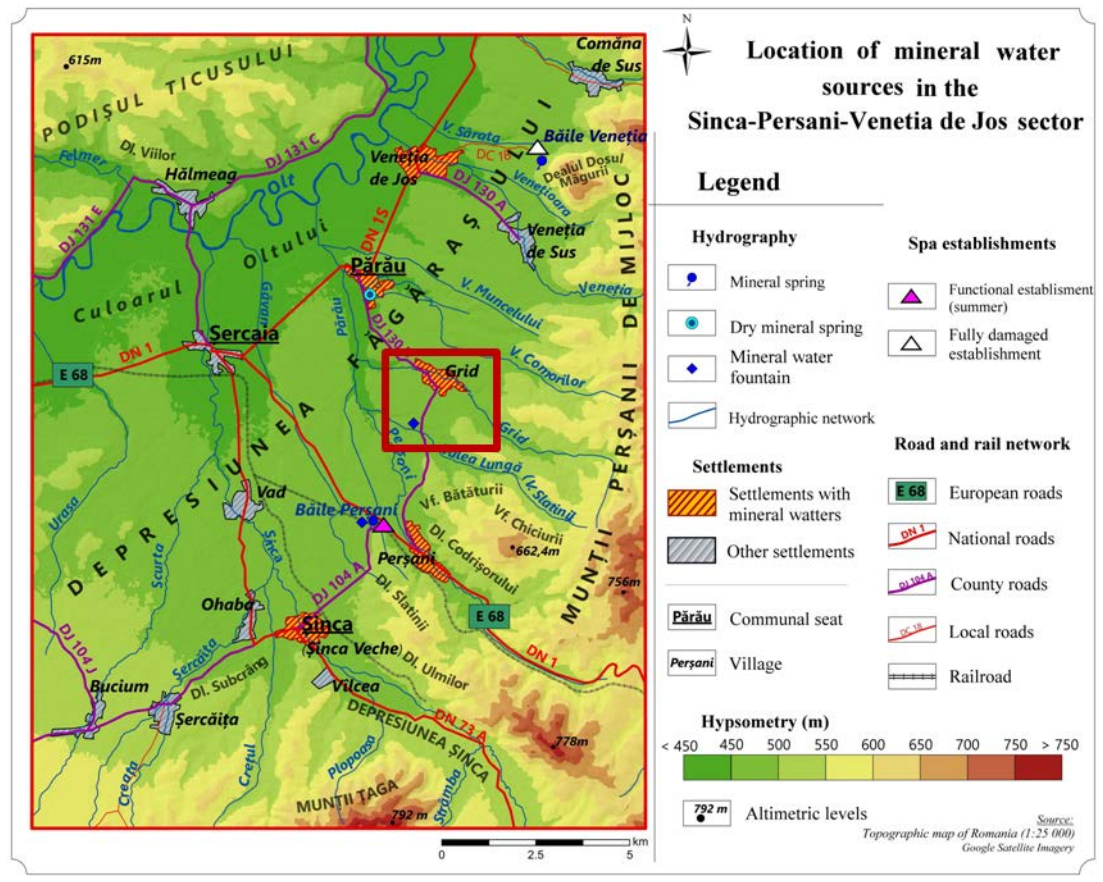

Fig. 1. Location of the Grid Village area (the red rectangle)

The mean multiannual air temperature in Grid Village is $8.3^{\circ} \mathrm{C}$ (climate parameter values cover the period 1961-2013 and were obtained by processing information from ROCADA database, Dumitrescu and Bîrsan, 2014). The average value for the warmest month (July) was $19.1^{\circ} \mathrm{C}$, and that of the coldest month (January) was $-4.06^{\circ} \mathrm{C}$. The highest temperature (absolute peak) for the overall period was $37.8^{\circ} \mathrm{C}$ (August 2012), and the lowest was $-30.8^{\circ} \mathrm{C}$ (January 1985). In terms of precipitation amounts, the mean value was $610 \mathrm{~mm} /$ year; the peak month was June $(87 \mathrm{~mm})$, and the driest was February $(28.5 \mathrm{~mm})$. According to the Köppen - Geiger climate classification system, the Grid Village area has a humid continental climate (Dfb type), characterized by mean temperatures below $22^{\circ} \mathrm{C}$ in July (warm summers) and below $3^{\circ} \mathrm{C}$ in January (Fig. 2). No significant precipitation difference between seasons (year-round precipitation).

Air temperature is directly influenced by sunshine duration, which can favour the extension of optimal conditions for sunbathing and therapeutic mud treatments. In the analyzed period, sunshine duration had a multiannual mean value of 1987 hours. July had an average of 259.6 hours, and December had 58.1 hours, 
while cloud cover values resulted in multiannual means of 6.2 tenths for December, and 5.0 tenths for August, with an annual mean of 7.6 tenths.

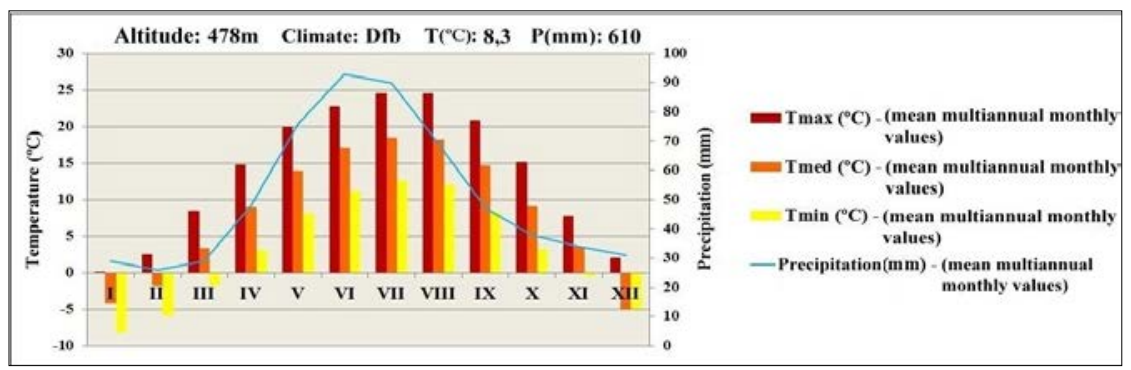

Fig. 2. Variation of monthly air temperature and precipitation values in Grid Village between 1961 and 2013 (Data source: Dumitrescu, Bîrsan, 2014)

Another important climate parameter for determining bioclimatic indices is the air's relative humidity. In the analysed period, the mean multiannual value was $79.7 \%$, which is close to what was recorded in Perşani and Veneţia de Jos. The month with the highest relative humidity was December (88.2\%), while the lowest values were recorded in May (73.5\%). The direction of prevailing winds in the area is west, northwest.

Vegetation primarily consists of secondary grasslands that alternate with agricultural lands. Hydrophilic and halophytic plants, which prefer humid (hydrosoils) or salt-rich (aquisalids) soils, can be found sporadically.

The mean values obtained for the analysed climate parameters (air temperature, precipitation, sunshine duration, etc.) and for the other environmental elements (vegetation, soils) are close to the ones recorded at Băile Perşani, which leads us to believe that Grid, too, has a sedative - indifferent hilly woodland climate, similar to that of Băile Perşani (Berlescu, 1971), with comparable bioclimatic index values (Ionac and Ciulache, 2008). This type of bioclimate does not require any special efforts in terms of the patients' adaptation to the local environment, regardless of the region they come from (Berlescu, 1998).

\section{LOCATION OF THE MINERAL SPRINGS IN GRID, AND THEIR CURRENT STATE}

Pascu (1927) mentioned two salt water springs in Stearaşu creek's valley (Valea Slatina/Valea Sărată), of which one was on the creek's right side and was the property of Grid Village, and the other was on the left side and was the property of Perşani Village (Fig. 3 a). At present, in the vicinity of Grid, only the spring captured in the well on the right side of Slatina creek still remains. The well is located approximately $40-50 \mathrm{~m}$ from the road (DJ $130 \mathrm{~B}$ ) that connects villages Perşani and Grid, and $\sim 1.4 \mathrm{~km}$ from Grid Village. It is located at an altitude of 457 ma.s.l. $( \pm 0.9 \mathrm{~m})$, and its geographic coordinates are: lat. N: $45^{\circ} 48^{\prime} 31.097$ "; long. E: $25^{\circ} 12^{\prime} 38.113 "$. The well used to be protected by a wooden shed, which has 
since been destroyed. Its stone walls form a rectangular shape (2 m long/1.70 m wide), and are $1.30 \mathrm{~m}$-deep (the drilling depth is however greater). The water surface is $0.15-0.20 \mathrm{~m}$ from the concrete edges around the well (Fig. $3 \mathrm{~b}$ ). It features a small drainage, so that the water in the well can reach nearby puddles. In July 2016, the well was covered with a "lid" - a board secured with several wooden planks - locals improvised in order to avoid accidents (Fig. 3 c). The spring water has not been analysed physically and chemically; in the past, it was only mentioned it was salty, used for household activities and to water animals (Pascu, 1927, discussions with locals, 2013).

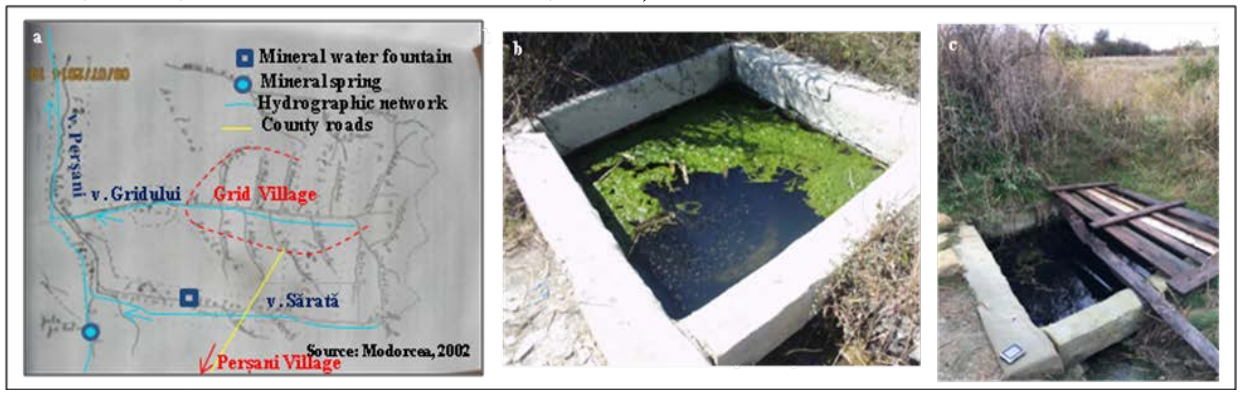

Fig. 3. The mineral water well in Grid Village: a) location map; b and c) current state (Source: a - Modorcea, 2002; b, c-Mereț, 2012, 2016)

\section{PHYSICO - CHEMICAL PARTICULARITIES OF THE MINERAL SPRING}

Between 2012 and 2015, water samples were collected from the spring captured in the well, and analysed at specialized laboratories (Water Quality Laboratory of the National Minetal Water Society - SNAM, in Bucharest, and at the Physico - chemical analyses laboratory of the Water Management Society SGA, in Braşov). Additional field measurements were performed using the Hanna 9828 multiparameter. A therapeutic mud sample collected in October 2016 was analysed at the Institute for Multidisciplinary Scientific and Technological Research (ICSTM) in Târgovişte. For the water sample analysed at SNAM, report results showed that the water is chlorosodic, bicarbonated, calcium-rich, with a $\mathrm{pH}$ of $6.97 \mathrm{pH}$ units (neutral character), conductivity of $(69.400 \mathrm{mS} / \mathrm{cm}$, total dissolved salts (TDS) of $34.700 \mathrm{mg} / \mathrm{l}$, and a carbon dioxide concentration (free $\mathrm{CO}_{2}$ ) of 184.8 $\mathrm{mg} / \mathrm{l}$. In terms of anions, the highest recorded values were chlorides $(\mathrm{Cl})$ with 29 , $672.34 \mathrm{mg} / \mathrm{l}$ bicarbonates $\left(\mathrm{HCO}_{3}{ }^{-}\right)$with $616.1 \mathrm{mg} / \mathrm{l}$, and sulphates $\left(\mathrm{SO}_{4}{ }^{2}\right)$ with $406.96 \mathrm{mg} / \mathrm{l}$. Nitrates $\left(\mathrm{NO}_{3}{ }^{-}\right)$and nitrites $\left(\mathrm{NO}_{2}\right)$ exceeded quantification limits, i.e. $4.63 \mathrm{mg} / \mathrm{l}$ for nitrates, and $0.07 \mathrm{mg} / \mathrm{l}$ for nitrites. With regard to cations, higher values were found for sodium $\left(\mathrm{Na}^{+}\right)$with $19.190 \mathrm{mg} / \mathrm{l}$, and calcium $\left(\mathrm{Ca}^{2+}\right)$ with 202 $\mathrm{mg} / \mathrm{l}$. The results of the S.G.A. Braşov's analysis indicated a bicarbonate concentration $\left(\mathrm{HCO}_{3}{ }^{-}\right)$of $607.56 \mathrm{~g} / \mathrm{l}$, while carbon dioxide $\left(\mathrm{CO}_{2}\right.$ liber) was 184.8 $\mathrm{mg} / \mathrm{l}$, which are close to the values obtained in the analysis performed by SNAM, Bucharest. Hanna 9829 multiparameter measurements indicated a constant water salinity of about $50 \mathrm{~g} / \mathrm{l}$ (Fig. 4). The average $\mathrm{pH}$ was 8.19 (values ranged from 7.70 
to $8.48 \mathrm{upH}$ ), mean water conductivity was $72.46 \mathrm{mS} / \mathrm{cm}$ (values ranged between 69.0 and $74.1 \mathrm{mS} / \mathrm{cm}$ ), TDS had a mean value of $36.54 \mathrm{~g} / \mathrm{l}$ (ranging from 35.60 to $37.41 \mathrm{~g} / \mathrm{l}$ ), and the average salinity was $50.15 \mathrm{~g} / \mathrm{l}$, and ranged between 48.70 and $51.50 \mathrm{~g} / \mathrm{l}$. While the mean water temperature was $11.23^{\circ} \mathrm{C}$, it must be mentioned that measurements were performed in the summer season, when air temperature reached $20^{\circ} \mathrm{C}$. Water temperature was lower $\left(10.5^{\circ} \mathrm{C}\right)$ in April 2015 , when air temperature reached $7.5^{\circ} \mathrm{C}$ (Fig. 4).

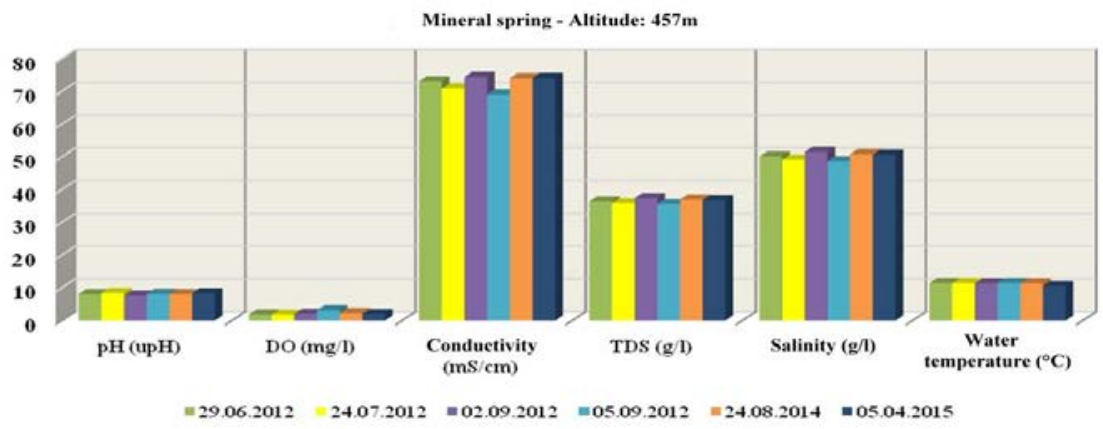

Fig. 4. Variation of physico-chemical parameters in the mineral water well in Grid, in the period 2012 - 2015

Compared to other mineral water springs in Braşov County, it was noticed that the mineral spring in Grid, alongside the ones in Mercheaşa, Racoş and Perşani, can be classed in the high mineralization category, which is determined by their geographic positioning in the salt grain-rich diapir region.

\section{THERAPEUTIC MUD}

Within the administrative limits of Grid Village there are also numerous emergences of salt-rich mineral waters, and the mineral salt surface deposits and vegetation decomposition resulted in the formation of a sapropelic mud that is similar to the one in Băile Perşani. The morphology imagery, obtained upon analysis of therapeutic mud samples at ICSTM in Târgovişte, using a scanning electron microscope (SEM) SU-70 coupled with an energy dispersive spectrometer (EDS), showed, for the Grid sample, a granular, compact structure, with no impurities (leaves, rocks, roots etc.), while the Perşani ample had a granular structure with coarse inclusions and other impurities: roots, various species of algae (Epithemia sp., Navicula sp., Cymbella sp., which is also probably due to the not entirely convenient sampling location. The EDS-based data (element distribution maps) also showed that, in terms of chemical composition, the Grid sample is homogeneous, the elements are distributed uniformly, except for sodium and chlorine (sodium chloride), which had granular distributions, while the Băile Perşani sample was fairly homogeneous, with evenly-distributed elements, except for sodium, chlorine, calcium and potassium, which had granular distributions. The 
atomic and mass percentages of the main chemical elements indicated the highest concentrations for oxygen and silicon (52\% and respectively 22\%).

\section{USE OF MINERAL WATERS AND THERAPEUTIC MUD IN THE GRID VILLAGE AREA}

Grid Village's therapeutic factors (mineral waters, therapeutic mud, similar bioclimate to that at Băile Perşani) have never been used in a spa. There haven't been any spa facilities, although Grid locals have submitted such proposals (Modorcea, 2002). However, locals and inhabitants of nearby settlements and Braşov come to Grid because, unlike Băile Perşani, everything is "free" here. People dig their own "tubs" in the therapeutic mud (Fig.5 a), which are then filled with salt water that warms up and is used for baths, alongside therapeutic mud baths, as attested by the interviews the authors conducted with locals (Fig. 5 b, c). The conditions that can be treated or ameliorated using the local chlorosodic mineral waters and therapeutic mud are mainly rheumatism, various forms of spondylosis (cervical, lumbar), gynecological disorders, arthroses, etc. (Berlescu, 1998). The area's natural therapeutic potential would thus be exploited in an entirely superior manner, instead of exclusively during the summer season. Also, spa tourism could be complemented by other forms of tourism for which the area is fitted (cultural/religious etc.), given the natural, historic and religious sightseeing objectives of the Perşani - Hoghiz area, which include the Fates' Temple cave complex, the Sf. Nectarie Monastery in Şinca Veche, and the historic sites and natural reservations found in the Comăna - Hoghiz area (Hoghiz castles, Comăna Cave, etc.).
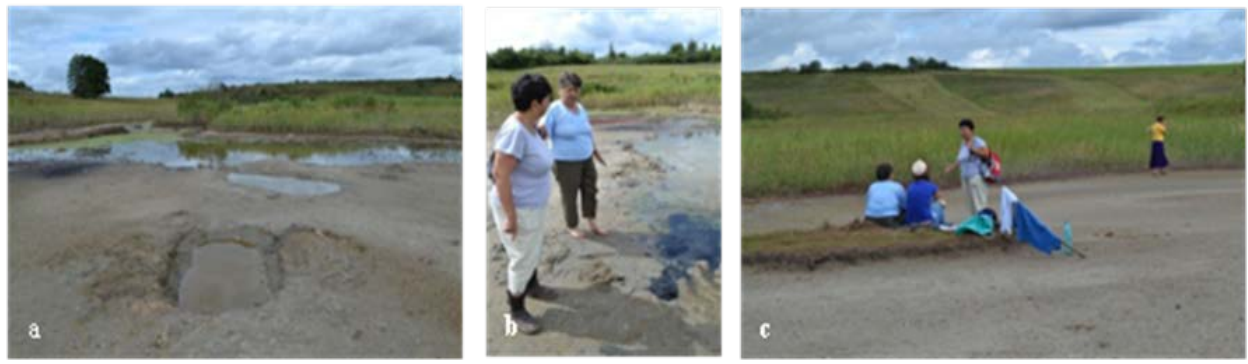

Fig. 5. Use of the therapeutic potential of therapeutic mud and mineral waters in the Grid Village area a) "tubs" for salt water collection; $b$ and $c$ ) interviews with locals in the therapeutic mud area (Author: Simion, 2014)

\section{CONCLUSIONS}

Grid Village, located in the vicinity of the tourist site Băile Perşani, features therapeutic factors (mineral waters, therapeutic mud and gentle, calming bioclimat) that have only been used in an isolated and rudimentary manner. The few specialized studies conducted in the area placed the local mineral water springs 
in the chlorosodic mineral water category, which was confirmed by the analyses performed in our study, in the 2012 - 2016 period. Given its therapeutic properties, chlorosodic mineral spring water can only be used externally and, paired with the Grid therapeutic mud, can ameliorate rheumatic conditions that affect, most notably, the population around Braşov. Ample specialized studies and significant investments from local and county policy makers, brought together in a coherent regional development program, are necessary in order to fully tap into Grid's spa potential and, perhaps, have it added in the tourist circuit of local importance. To this end, a highly important source could be the European Structural and Investment Funds, made available to Romania under Regional Operational Programmes.

\section{REFERENCES}

1. Bender, T., Bálint, G., Prohászka, Z., Géher, P., Tefner, I. K. (2014), Evidencebased hydro- and balneotherapy in Hungary - a systematic review and metaanalysis, International Journal of Biometeorology 58, 311-323.

2. Berlescu, E. (1971), Spa resorts in the past and present day, Medical Publishing House, Bucharest.

3. Berlescu, E. (1998), Encyclopedia of Romania balneoclimatology, All Publishing House, Bucharest.

4. Ciupagea, D., Paucă, M., Ichim, Tr. (1970), Geology of the Transylvanian Depression, R.S.R. Academy Publishing House, Bucharest.

5. Dumitrescu, A., Bîrsan, M.V. (2014), ROCADA: a gridded daily climatic dataset over Romania (1961- 2013 for nine meteorological variables. Natural Hazards 78(2): 1045-1063 DOI: 10.1007/s11069-015-1757-z.

6. Fraioli, A., Serio, A., Mennuni, G., Ceccarelli, F., Petraccia, L., Fontana, M., Grassi, M., Valesini, G. (2011), A study on the efficacy of treatment with mud packs and baths with Sillene mineral water (Chianciano Spa Italy) in patients suffering from knee osteoarthritis, Rheumatology International 31,10, 1333-1340.

7. Gutenbrunner C, Bender T, Cantista P, Karagülle Z. (2010), A proposal for a worldwide definition of health resort medicine, balneology, medical hydrology and climatology, International Journal of Biometeorology 54, 495-507.

8. Ionac, N., Ciulache, S. (2008), Bioclimatic atlas of Romania, Ars Docendi Publishing House, Bucharest.

9. Modorcea, V. (2002), Monography of Grid Village in Ţara Făgăraşului, Tibo Publishing House, Bucharest.

10. Pascu M. R. (1927), Quarries and mineral waters in Braşov County, Bucovina Graphic Arts Institute, I.E. orouțiu, Bucharest.

11. Petit, Al. (1922), Monography of Braşov County and City, Unirea Cartographic Institute Publishing House, Braşov County.

12. Sukenik, S., Flusser, D., Abu-Shakra, M. (1999), The role of spa therapy in various rheumatic diseases, Rheumatology Disease Clinics of North America 25, 4, 883-897.

13. *** File 1- 208 (Zizin 1887 - 1949; 481/1944), National Archives Braşov County Department. 